\title{
Checklist of the Umbelliferae family in the herbarium of Iraq natural history museum
}

\author{
Khansaa Rasheed Al-Joboury * \\ Iraq Natural History Research Center and Museum, University of Baghdad, Baghdad, Iraq.
}

GSC Biological and Pharmaceutical Sciences, 2021, 15(03), 177-181

Publication history: Received on 07 May 2021; revised on 10 June 2021; accepted on 12 June 2021

Article DOI: https://doi.org/10.30574/gscbps.2021.15.3.0160

\begin{abstract}
The aim of this study is to make the inventory for Umbelliferae family for the purpose of identifying the samples that were collected over long periods and saved in the herbarium of Iraq Natural History Museum/ University of Baghdad. We found that the herbarium plants were very large and varied from different parts for Iraq, in different and varied environments, which collected and arranged according to a very specific system in the herbarium for remaining an important source to all graduate students and researchers to take advantage for these plants. Also, the flowering and fruiting periods for these plants in Iraq were recorded in different regions. Most these plants begin to flower in the spring and thrive at fields and farms.
\end{abstract}

Keywords: Umbelliferae; Herbarium; Iraq; Natural; History; Museum

\section{Introduction}

Umbelliferae, one for the best-known families for flowering plants have 300-455 genera and 3000- 3700 species [1]. The family Umbelliferae is very rich at secondary metabolites [2]. The synthesis for essential oils and oleoresin, secreted in schizogenous canals at root, stem, leaves and inflorescence, which a characteristic feature for this family [3]. So Apiaceae is cosmopolitan, and particularly abundant at the northern hemisphere, temperate regions and rare at tropics [4]. The species in the family Umbelliferae were aromatic plant, have a distinctive flavor and diverse volatile compounds in their fruits and leaves $[5,6,7]$.

Umbelliferae species distributed almost all over the world, and are diverse at temperate climatic areas, like Eurasia and North America. They are quite rare at tropical humid regions which limited in high mountains. The Apiaceae species are present at all types of habitats, in sea-level to alpine zones: aquatic biotopes, grasslands, grazed pastures, forests have their clearings and margins, screes, rocky hills, cliffs,, open sandy, gravelly soils, steppes, cultivated fields, fallows, waste grounds and road sides $[8,9,10]$.

\section{Material and methods}

The specimens of Umbelliferae family in various habitats for Iraq and saved at the herbarium for Iraq Natural History Museum was written down and studied the geographical distribution. So used many taxonomic keys identification and diagnosed genera such as: $[11,12,13]$.

\footnotetext{
* Corresponding author: Khansaa Rasheed Al-Joboury

Iraq Natural History Research Center and Museum, University of Baghdad, Baghdad, Iraq. 


\section{Results and discussion}

The checklist of Umbelliferae in the herbarium of Iraq Natural History Museum showed the genera as fallow $[14,15,16,17,18]$ :

\subsection{Ammi L.}

In the herbarium of Iraq Natural History Museum, it was found two species which were they Ammi majus L. and Ammi visnaga (L.) Lam.

HAB. Ammi majus L., gravelly hillsiodes, along ditches in fields, alt. 50-400 m, fl. And fr. Apr.-Jun.

HAB. Ammi visnaga (L.) Lam., moist places, banks of ditches, rice fields, alt. 50-1400 m, fl. and fr. May-Aug.

\subsection{Anethum L.}

In the herbarium of Iraq Natural History Museum, it was found one species which was Anethum graveolens L.

HAB. Anethum graveolens L., In gradens, orchards, fields and waste land, alt. up to 700m, fl. And fr. Mar.- May.

\subsection{Anisosciadium DC.}

In the herbarium of Iraq Natural History Museum, it was found the genus Anisosciadium DC.

\subsection{Ainsworthia Boiss.}

In the herbarium of Iraq Natural History Museum, it was found one species which was Ainsworthia trachycarpa Boiss.

HAB. Ainsworthia trachycarpa Boiss., lower mountains weed in fig garden, alt. 500-1000 m., fl. And fr. Apr.- May.

\subsection{Apium $L$.}

In the herbarium of Iraq Natural History Museum, it was found one species which was Apium graveolens L.

HAB. Apium graveolens L., Damp places, along streams, gardens, alt. up to 500 m, fl. and fr. Apr.- Jun.

\subsection{Artedia L.}

In the herbarium of Iraq Natural History Museum, it was found one species which was Artedia squamata L.

HAB. Artedia squamata L., on mountain slopes and stony hillsid, alt. 150- 1300 m., fl. and fr. Apr.- Jun.

\subsection{Bunium L.}

In the herbarium of Iraq Natural History Museum, it was found one genus which was Bunium L.

\subsection{Bupleurum $L$.}

In the herbarium of Iraq Natural History Museum, it was found two species which were they Bupleurum kurdicum Boiss. And Bupleurum lancifolium Hornem.

\subsection{Cachrys L.}

In the herbarium of Iraq Natural History Museum, it was found one genus which was Cachrys L.

\subsection{Caucalis L.}

In the herbarium of Iraq Natural History Museum, it was found one genus which was Caucalis L.

\subsection{Chaerophyllum L.}

In the herbarium of Iraq Natural History Museum, it was found one genus which was Chaerophyllum $\mathrm{L}$. 


\subsection{Coriandrum L.}

In the herbarium of Iraq Natural History Museum, it was found one species which was Coriandrum sativum L.

HAB. Coriandrum sativum L., cultivated as a garden herb, alt. 500-1000 m., fl. And fr. Mar.- May.

\subsection{Daucus L.}

In the herbarium of Iraq Natural History Museum, it was found one species which was Daucus carota L.

HAB. Daucus carota L., mountains, waste land in garden, alt. 50-1000 m., fl. And fr. Apr.-Aug.

\subsection{Ducrosia Boiss.}

In the herbarium of Iraq Natural History Museum, it was found one species which was Ducrosia anethifolia (DC.) Boiss. HAB. Ducrosia anethifolia (DC.) Boiss., desert, on sandy, sandy gravel soils, alt. 50-700 m., fl. and fr. Jun.- Jul.

\subsection{Eryngium $L$.}

In the herbarium of Iraq Natural History Museum, it was found one genus which was Eryngium L.

\subsection{Falcaria Fabr.}

In the herbarium of Iraq Natural History Museum, it was found one species which was Falcaria vulgaris Bernh.

HAB. Falcaria vulgaris Bernh., Mountain slopes, in fields and waste land, alt. 250-1550 m., fl. and fr. Jun-Sep.

\subsection{Ferula L.}

In the herbarium of Iraq Natural History Museum, it was found one species which was Ferula orientalis L.

HAB. Ferula orientalis L., on the mountain, among rocks, alt. up to $1400 \mathrm{~m}$, fl. And fr. Jun.- Jul.

\subsection{Ferulago W.D.J. Koch}

In the herbarium of Iraq Natural History Museum, it was found one genus which was Ferulago angulata (Schltdl.) Boiss. And Ferulago brachyloba Boiss. \& Reut.

\subsection{Foeniculum Mill.}

In the herbarium of Iraq Natural History Museum, it was found one genus which was Foeniculum Mill.

\subsection{Johrenia DC.}

In the herbarium of Iraq Natural History Museum, it was found one genus which was Johrenia DC.

\subsection{Ormosciadium Boiss.}

In the herbarium of Iraq Natural History Museum, it was found one genus which was Ormosciadium Boiss.

\subsection{Petroselinum Hill}

In the herbarium of Iraq Natural History Museum, it was found one genus which was Petroselinum Hill

\subsection{Myrrhoides nodosa (L.) Cannon}

In the herbarium of Iraq Natural History Museum, it was found one species which was Myrrhoides nodosa (L.) Cannon HAB. Myrrhoides nodosa (L.) Cannon, lower mountain, on stony clay, alt. 700-1400 m., fl. and fr. May-Jun.

\subsection{Pimpinella L.}

In the herbarium of Iraq Natural History Museum, it was found one species which was Pimpinella anisum L. 
HAB. Pimpinella anisum L., rare in Iraq.

\subsection{Smyrnium L.}

In the herbarium of Iraq Natural History Museum, it was found one genus which was Smyrnium L.

\subsection{Torilis Adans.}

In the herbarium of Iraq Natural History Museum, it was found one species which was Torilis leptophylla (L.) Rchb.f.

HAB. Torilis leptophylla (L.) Rchb.f., on mountain in grassy patches, weed in field, alt. 50-1400 m., fl. and fr. Apr.-Jun.

\subsection{Trachyspermum Link}

In the herbarium of Iraq Natural History Museum, it was found one species which was Trachyspermum ammi (L.) Sprague.

\section{Conclusion}

The study showed many of the genus and species of the Umbelliferae family which saved in the herbarium of Iraq Natural History Museum and their distribution in various, so they are very important widespread plant families and resist many difficult environmental conditions. So, that will be a reference to many researchers and those interested at this aspect.

\section{Compliance with ethical standards}

\section{Acknowledgments}

The author is grateful to the university of Baghdad to helpe me completing this research.

\section{References}

[1] Amiri MS, Joharchi MR. Ethnobotanical knowledge of Apiaceae family in Iran: A review. Avicenna Journal of Phytomedicine. 2016; 6(6): 621-635.

[2] Ajani Y, Ajani A, Cordes JM, Watson MF, Downie SR. Phylogenetic analysis of nrDNA ITS sequences reveals relationships within five groups of Iranian Apiaceae subfamily Apioideae. Taxon. 2008; 57: 383-401.

[3] Olle M, Bender I. The content of oils in umbelliferous crops and its formation. Agronomy Reasearch. 2010; 8: 687696.

[4] Pimenov MG. Proposal to conserve the name Carum persicum (Bunium persicum, Elwendia persica) against Sium cyminosma (Umbelliferae). Taxon. 2013; 66(3).

[5] Ajani Y, Bull-Hereñu K, Claßen-Bockhoff R. Patterns of flower development in Apiaceae-Apioideae. Flora. 2016; 221: 38-17.

[6] Azizian D, Yousefzadi M, Eftekhar F, Ali H. Pollen morphology of the genera Diplotaenia (Apiaceae) in Iran. The Iranian Journal of Botany. 2003; 10: 35-40.

[7] Dar ZA, Zeerak NA, Wani SA, Khan MH. Morpho-characterization of different populations of black caraway (Bunium persicum Bioss. Fedts) with respect to yield and yield traits across important growing sites of Kashmir Valley. Journal of Agricultural Biotechnology and Sustainable Development. 2011; 3: 60-64.

[8] Chahota RK, Sharma V, Ghani M, Sharma TR, Rana JC, Sharma SK. Genetic and phytochemical diversity analysis in Bunium persicum populations of north-western Himalaya. Physiology and Molecular Biology of Plants. 2017; 23(2): 429-441.

[9] Degtjareva GV, Kljuykov EV, Samigullin TH, Valiejo-Roman CM, Pimenov MG. ITS phylogeny of Middle Asian geophilic Umbelliferae-Apioideae genera with comments on their morphology and utility of psbA-trnH sequences. Plant Systematics and Evolution. 2013; 299(5): 985-1010. 
[10] Duran A, Doğan B, Duman H, Martin E, Öztürk M, Çetin Ö. Taxonomic studies on the genus Rhabdosciadium (Apiaceae) with particular reference to Turkish species and their relationships with some closely related genera. Biologia. 2010; 65.

[11] The Plant List. Version 1.1 Published on the Internet: http://www.theplantlist.org/ (accessed 1 September 2018). 2013.

[12] Ghazanfar SA, Edmondson JR. Flora of Iraqi. Vol.5. Ministry of Agriculture and Agarain reform. Baghdad, Iraqi. 2013.

[13] Klimko M, Truchan M Sobisz Z. Anther and pollen morphology of native and alien species of the genera Heracleum L. (Apiaceae) in Poland. Botanika-Steciana. 2012; 16: 5-14.

[14] Moghaddam M, Pirbalouti AG. Agro-morphological and phytochemical diversity of Iranian Cuminum cyminum accessions. Industrial Crops and Products. 2017; 99: 205-213.

[15] Punt W, Hoen PP, Blackmore S, Nilsson S, Le Thomas A. Glossary of pollen and spore terminology. Review of Palaeobotany and Palynology. 2007; 143: 1-81.

[16] Heikhbahaei N, Rezanejad F, Mirtadzadini SM. The morphological and anatomical studies of inflorescence and male flower in Pycnocycla nodiflora Decne. ex Boiss. (Apiaceae). Journal of Biology of Iran. 2014; 19: 73-96.

[17] Khansaa RA, Lubab GA, Sukeyna AA. Morphological, anatomical and numerical taxonomy studies for some species of the fabaceae family. Journal of Biodiversity and Environmental Sciences. 2017; 11(5): 117-123.

[18] Al-Joboury KR. Review with checklist of Fabaceae in the herbarium of Iraq natural history museum. GSC Biological and Pharmaceutical Sciences. 2021; 14(03): 137-142. 